\title{
プリン受容体ヘテロ多量体形成が血小板機能に与える影響の解析
}

\author{
鈴木登紀子†
}

\section{Hetero-oligomerization and Functional Interaction between Purinergic Receptors Expressed in Platelets to Regulate Platelet Shape Change}

\author{
Tokiko Suzuki ${ }^{\dagger}$ \\ Department of Cellular Signaling, Graduate School of Pharmaceutical Sciences, \\ Tohoku University; 6-3 Aoba, Aramaki, Aoba-ku, Sendai 980-8578, Japan.
}

(Received May 26, 2015)

\begin{abstract}
Adenosine and its precursors, ATP and ADP, exert various physiological effects via binding to purinergic receptors. We previously used co-immunoprecipitation, bioluminescence resonance energy transfer (BRET) and immunoelectron microscopy to demonstrate the hetero-oligomerization of purinergic receptor subtypes. Furthermore, pharmacological studies found significant changes in receptor-mediated signaling in human embryonic kidney (HEK) 293T cells co-transfected with these receptors. These findings suggest that heterodimers of purinergic receptors may have distinct pharmacological profiles, possibly due to dimerization-induced conformational changes, further suggesting that heterodimerization may be employed to "fine-tune" purinergic receptor signaling. Adenosine $A_{2 A}$ receptor $\left(A_{2 A} R\right), P 2 Y_{1}$ receptor $\left(\mathrm{P} 2 \mathrm{Y}_{1} \mathrm{R}\right)$ and $\mathrm{P} 2 \mathrm{Y}_{12}$ receptor $\left(\mathrm{P}_{2} \mathrm{Y}_{12} \mathrm{R}\right)$ are predominantly expressed on human platelets. ADP activates human platelets by stimulating both $\mathrm{P} 2 \mathrm{Y}_{1} \mathrm{R}$ and $\mathrm{P} 2 \mathrm{Y}_{12} \mathrm{R}$, which act sequentially and in concert to achieve complete platelet aggregation. In contrast, adenosine stimulates Gs-coupled $\mathrm{A}_{2 \mathrm{~A}} \mathrm{R}$, followed by activativation of adenylate cyclase, leading to an increase in intracellular cAMP levels, which potently inhibits platelet activation. We examined the heterooligomerization and functional interactions of $A_{2 A} R, P 2 Y_{1} R$, and $P 2 Y_{12} R$. In HEK293T cells triply expressing all three receptors, hetero-oligomerization was observed among the three receptors. Additionally, $\mathrm{P} 2 \mathrm{Y}_{1} \mathrm{R}$ agonist-evoked $\mathrm{Ca}^{2+}$ signaling was significantly inhibited by co-treatment with an $\mathrm{A}_{2 \mathrm{~A}} \mathrm{R}$ antagonist in HEK293T cells. In human platelets, we identified endogenous $A_{2 A} R / P 2 Y_{1} R$ and $A_{2 A} R / P 2 Y_{12} R$ heterodimers. We also observed functional $\mathrm{Ca}^{2+}$-signaling-related cross-talk similar to those found in HEK293T cells, and found that they appeared to affect platelet shape. These results collectively suggest that intermolecular signal transduction and specific conformational changes occur among components of the hetero-oligomers formed by these three receptors.
\end{abstract}

Key words_ - purinergic receptor; heterooligomer; ADP; adenosine; platelet shape change

\section{1. はじめに}

$\mathrm{G}$ タンパク質共役型受容体 (G protein coupled receptor; GPCR）は既に多くの治療薬のターゲット となっているが, 単独の受容体としての機能だけで なく他の GPCR とのへテロ多量体形成の例が近年 活発に報告されている. ${ }^{1)}$ GPCR ヘテロ多量体形成 の研究に関してはほとんどの場合培養細胞強制発現 系を用いて行われているのが現状であるが，in

東北大学大学院薬学研究科細胞情報薬学分野 (T9808578 仙台市青葉区荒巻字青葉 6-3)

現所属: ${ }^{+}$富山大学大学院医学薬学研究部 (医学) 分 子医科薬理学講座（下930-0194 富山市杉谷 2630 番地） e-mail: tokikosu@med.u-toyama.ac.jp 本総説は, 平成 26 年度日本薬学会東北支部奨励賞の受 賞を記念して記述したものである. vivo での多量体形成と生理機能の関係を示す興味 深い研究も報告され始めている。例えば，マウスの アンギオテンシン $\mathrm{AT}_{1}$ 受容体 $\left(\mathrm{AT}_{1} \mathrm{R}\right)$ とセクレチ ン受容体（SecR）のへテロ多量体形成を妨げるぺ プチドを利用した in vivo 実験により，それらの多 量体形成が飲水行動を制御しているという見解が報 告された. ${ }^{2)}$ また以下のような他のアプローチも報 告されている. ${ }^{3,4)}$ すなわち， $\mu$ オピオイド受容体 ( $\mu$ opioid receptor; MOR) と $\delta$ オピオイド受容体 ( $\delta$ opioid receptor; DOR), MOR と代謝型グル夕 ミン酸受容体 5 (metabotropic glutamate receptor 5; mGluR5）はそれぞれへテロ多量体を形成するが, MOR アゴニストの Oxymorphone と DOR アンタ ゴニストの Naltrindole, Oxymorphone と mGluR5 
アンタゴニストの M-MPEP2 を連結した二価リガ ンドが合成された. ${ }^{3,4)}$ Oxymorphone-Naltrindole, Oxymorphone-M-MPEP2 ともに，多量体を形成し ている 2 つ受容体分子に同時に結合することを考 慮して, リンカーの長さが調節されている. ${ }^{3,4)}$ マウ スを用いた実験により，Oxymorphone-Naltrindole， Oxymorphone-M-MPEP2 ともに低濃度でモルヒネ 様の効果を示し, 副作用も軽減されるという興味深 い結果が発表されている。. ${ }^{3,4)}$ GPCR ヘテロ多量体 は培養細胞強制発現系での研究が先行していたた め，生理的意義を疑問視する声もあったが，少なく とも $\mathrm{AT}_{1} \mathrm{R} / \mathrm{SecR}, \mathrm{MOR} / \mathrm{DOR}, \mathrm{MOR} / \mathrm{mGluR} 5$ のへ テロ多量体形成には生理的役割があることが明らか になった. ${ }^{2-4)}$ 前述のように GPCR は多くの治療薬 のターゲットとなっているが，これまでのように単 独としての GPCR を創薬ターゲットとする戦略に は限界がある。シーズが枯渇しつつある現代におい て，GPCR ヘテロ多量体は新たな創薬ターゲット として期待を集めている.

2. プリン受容体間ヘテロ多量体形成（ $A_{1}$ 受容 体 $/ \mathbf{P}_{2} \mathrm{Y}_{1}$ 受容体, $\mathrm{A}_{1}$ 受容体 $/ \mathbf{P}^{2} \mathrm{Y}_{2}$ 受容体 $)$

細胞内の主要なエネルギー源である ATP は, 細 胞外ではシグナル伝達物質として機能することが知 られている. ATP は細胞外で種々の加水分解酵素 により, ATP $\rightarrow \mathrm{ADP} \quad($ アデノシン二リン酸 $) \rightarrow$ AMP (アデノシン一リン酸) $\rightarrow$ アデノシンへと速や かに代謝され，また再生酵素によって生合成され， その局所濃度が厳密に調節されている. ${ }^{5)} \mathrm{ATP}$, ADP, uridine 5'-triphosphate (UTP) 等のヌクレオ チドは，P2 受容体（GPCR である P2Y 受容体とイ オンチャネルである $\mathrm{P} 2 \mathrm{X}$ 受容体に分類) に結合し, 神経細胞保護や痛みの伝達などに深く係わってい る. ${ }^{6)}$ 一方でアデノシンは, GPCR であるアデノシ ン受容体に結合し，交感神経・副交感神経作用の減 弱，睡眠の調節，虚血による脳障害の防止など，多

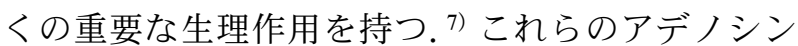
受容体と P2 受容体はプリン受容体と総称され, 中 枢神経系から末梢組織にまで広範囲に発現, 機能し ている. リガンド同士に上記のような密接な関連性 があるため，筆者らはプリン受容体間にも直接的な 相互作用があり，相互作用により機能が調節される 可能性を考え，本研究に着手した。

アデノシン受容体には, $\mathrm{A}_{1}, \mathrm{~A}_{2 \mathrm{~A}}, \mathrm{~A}_{2 \mathrm{~B}}, \mathrm{~A}_{3}$ の 4 種
類のサブタイプがあり， P2Y 受容体には， $\mathrm{P} 2 \mathrm{Y}_{1,2,4,6,11,12,13,14}$ のサブタイプがある.これらの うち，筆者らはまず中枢神経系等での共発現が知ら れる $A_{1}$ 受容体・P2 $Y_{1}$ 受容体 $\left(A_{1} R / P 2 Y_{1} R\right)$, 及び $\mathrm{A}_{1}$ 受容体・P2 $\mathrm{Y}_{2}$ 受容体 $\left(\mathrm{A}_{1} \mathrm{R} / \mathrm{P} 2 \mathrm{Y}_{2} \mathrm{R}\right)$ のヘテロ 多量体形成の解析を行った。 $A_{1} R / P 2 Y_{1} R$ あるいは $\mathrm{A}_{1} \mathrm{R} / \mathrm{P} 2 \mathrm{Y}_{2} \mathrm{R}$ の組み合わせでヒト胎児腎由来 HEK293T 細胞に共発現させると, 免疫共沈降法に よりどちらの組み合わせによっても共沈降がみられ た。 ${ }^{8,9)}$ さらにそれぞれの受容体にドナー（レニラル シフェラーゼ）とアクセプター（変異型 GFP）を 融合させた形で共発現させ，共鳴エネルギー転移に よって目的タンパク質の近接から多量体形成を評価 する bioluminescence resonance energy transfer (BRET) 解析も行い，2 種の受容体間での多量体形 成を明らかにすることができた. ${ }^{10,11)} \mathrm{A}_{1} \mathrm{R} / \mathrm{P} 2 \mathrm{Y}_{2} \mathrm{R}$ については免疫電子顕微鏡法によっても多量体形成 を証明した. ${ }^{12)}$

次に多量体形成によって受容体のシグナル伝達に 変化が及ぼされるかどうかを検討した， $\mathrm{A}_{1} \mathrm{R}$ には 主に $\mathrm{Gi}$ が， $\mathrm{P} 2 \mathrm{Y}_{1} \mathrm{R}, \mathrm{P} 2 \mathrm{Y}_{2} \mathrm{R}$ には主に $\mathrm{Gq}$ が共役し ているが, $\mathrm{A}_{1} \mathrm{R} / \mathrm{P} 2 \mathrm{Y}_{1} \mathrm{R}$ 共発現細胞では $\mathrm{P} 2 \mathrm{Y}_{1} \mathrm{R}$ の選 択的アゴニストである adenosine $5^{\prime}-O$ - (2thiotriphosphate）（ADP $\beta \mathrm{S} ）$ の添加により， Gi 経 由のアデニル酸シクラーゼ阻害がみられ, 百日咳毒 素による $\mathrm{Gi}$ 阻害及び $\mathrm{A}_{1} \mathrm{R}$ の選択的アンタゴニスト 8-cyclopentyl-1,3-dipropylxanthine（DPCPX）によ りブロックされた. ${ }^{8)}$ つまり, $\mathrm{A}_{1} \mathrm{R}$ は $\mathrm{P} 2 \mathrm{Y}_{1} \mathrm{R}$ とへテ 口多量体を形成することで構造が変化し， P $2 \mathrm{Y}_{1} \mathrm{R}$ のアゴニストを結合して Gi 経由の反応が起こるよ うになったと考えることができる（Fig. 1)。また， $\mathrm{Gq}$ 経由の反応は $\mathrm{P} 2 \mathrm{Y}_{1} \mathrm{R}$ 単独発現細胞と同様にみ られたことから，P $2 \mathrm{Y}_{1} \mathrm{R}$ には構造変化は起こらな いことが示唆された。一方で, $\mathrm{A}_{1} \mathrm{R} / \mathrm{P} 2 \mathrm{Y}_{2} \mathrm{R}$ 共発現 細胞では， $\mathrm{P} 2 \mathrm{Y}_{2} \mathrm{R}$ にアゴニストとして ATP と同程 度のアフィニティーで作用する UTP を作用させる ことで， $\mathrm{A}_{1} \mathrm{R}$ 選択的アゴニスト N6-cyclopentyladenosine（CPA）刺激による $\mathrm{Gi}$ 経由の反応が 阻害された. ${ }^{9)}$ そして，UTP とアデノシン受容体非 選択的アゴニストである $5^{\prime}-N$-ethylcarboxamidoadenosine（NECA）を同時に添加すると Gq 経由 の反応は相乗的に促進され, 相乗的促進は DPCPX ではブロックされなかった。つまり， $\mathrm{A}_{1} \mathrm{R}$ は $\mathrm{P} 2 \mathrm{Y}_{2}$ 


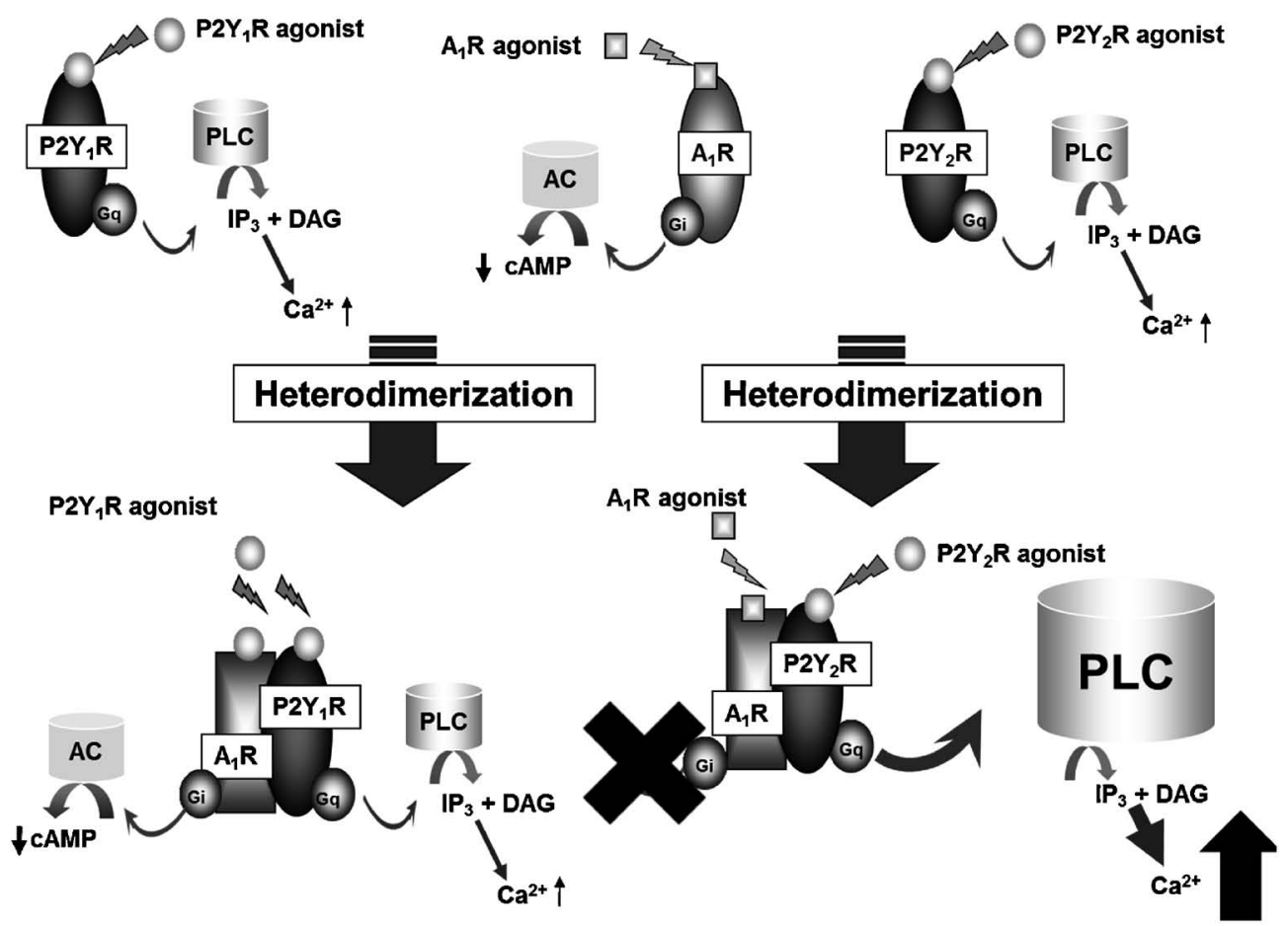

Fig. 1. Presumed Signaling Pathways Induced by Heterodimers of $A_{1} R / P 2 Y_{1} R$ (left) and $A_{1} R / P 2 Y_{2} R$ (right) in Co-transfected HEK293T Cells

Following the heteromeric oligomerization of $A_{1} R$ and $P 2 Y_{1} R$, a potent $P_{2} Y_{1} R$ agonist binds to an $A_{1} R$ binding pocket and inhibits adenylyl cyclase activity via the Gi/o protein-linked effector system. On the other hand, after heteromeric oligomerization of $A_{1} R$ and $P 2 Y_{2} R$, increase in the intracellular Ca ${ }^{2+}$ levels induced by activated $P 2 Y_{2} R$ was synergistically enhanced upon simultaneous addition of an $A_{1} R$ receptor agonist. The $A_{1} R$-coupled inhibitory activity of adenylate cyclase was attenuated upon simultaneous addition of $\mathrm{A}_{1} \mathrm{R}$ and $\mathrm{P} 2 \mathrm{Y}_{2} \mathrm{R}$ agonists. AC, adenylyl cyclase; DAG, diacylglycerol; $\mathrm{IP}_{3}$, inositol trisphosphate; PLC, phospholipase $\mathrm{C}$.

$\mathrm{R}$ とヘテロ多量体を形成することで, $\mathrm{P} 2 \mathrm{Y}_{1} \mathrm{R}$ との ときとは違った構造変化を生じ, 両方のアゴニスト 刺激で Gi 経由の反応は阻害され，Gq 経由の反応 は相乗的に促進されるようになったと考えられる (Fig. 1)。 $\mathrm{P} 2 \mathrm{Y}_{1} \mathrm{R}$ と $\mathrm{P} 2 \mathrm{Y}_{2} \mathrm{R}$ はアミノ酸配列につい ては $50 \%$ 以上の相同性がみられ，ともに中枢神経 系に発現し， Gq に共役するなど類似点が多くみら れるが， $A_{1} \mathrm{R}$ とのへテロ多量体形成に関しては異 なる性質を示すことが以上の研究によって示唆され た.

以上に述べた $A_{1} R / P 2 Y_{1} R$ あるいは $A_{1} R / P 2 Y_{2} R$ の共発現による特異的シグナル変化は，すべて培養 細胞に強制発現させた場合の結果であるが， $\mathrm{A}_{1} \mathrm{R} /$ $\mathrm{P} 2 \mathrm{Y}_{1} \mathrm{R}$ に関しては，ラット脳でも免疫染色法及び 免疫共沈降法で受容体共局在とへテロ多量体形成が 明らかにされている. ${ }^{13)} \mathrm{A}_{1} \mathrm{R} / \mathrm{P} 2 \mathrm{Y}_{2} \mathrm{R}$ においても, 免疫染色法, 免疫共沈降法, 免疫電子顕微鏡法に よって, ラット脳での共局在と多量体形成を立証し

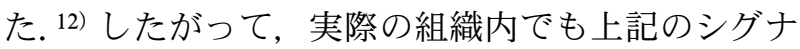
ル伝達の変化が起こっている可能性があり, $\mathrm{A}_{1} \mathrm{R} /$ $\mathrm{P}_{2} \mathrm{Y}_{1} \mathrm{R}$ あるいは $\mathrm{A}_{1} \mathrm{R} / \mathrm{P} 2 \mathrm{Y}_{2} \mathrm{R}$ のヘテロ多量体の生理
的役割についての解析が必要である.

3. プリン受容体間ヘテロ多量体形成 $\left(\mathrm{A}_{2 \mathrm{~A}}\right.$ 受容 体 $/$ P2 $_{1}$ 受容体 $/$ P2 $Y_{12}$ 受容体)

血小板は直径約 2-4 $\mu \mathrm{m}$ の扁平円盤状の形態を有 し，止血に欠かすことのできない血球成分である. 様々な外部刺激により活性化し，血小板内顆粒の放 出, 形態変化に引き続き, 活性化された接着膜タン パク質のインテグリンを介して細胞外基質や血小板 同士と接着し，凝集塊を形成する. ${ }^{14)}$ 古くより， ADP は強力な血小板凝集誘発物質として知られて おり，その受容体である GPCR 型プリン受容体が 血小板に高発現することが報告されてきた. ${ }^{15)} \mathrm{ADP}$ 受容体である $\mathrm{P} 2 \mathrm{Y}_{1}$ 受容体 $\left(\mathrm{P} 2 \mathrm{Y}_{1} \mathrm{R}\right)$ は主に $\mathrm{Gq}$ と 共役しており，ADPによる血小板の活性化や形態 変化に重要な役割を持つ一方, $\mathrm{P} 2 \mathrm{Y}_{12}$ 受容体 $\left(\mathrm{P} 2 \mathrm{Y}_{12} \mathrm{R}\right)$ は Gi と共役し, 接着タンパク質の活性 化を通じて ADP による血小板凝集の中心的役割を 担う。また，アデノシン受容体である $\mathrm{A}_{2 \mathrm{~A}}$ 受容体 $\left(\mathrm{A}_{2 \mathrm{~A}} \mathrm{R}\right)$ は $\mathrm{Gs}$ と共役しており，血小板の活性化を 抑制することが知られている. ${ }^{16)}$ 筆者らは, 血小板 に高発現し，その機能に重要な役割を果たしている 


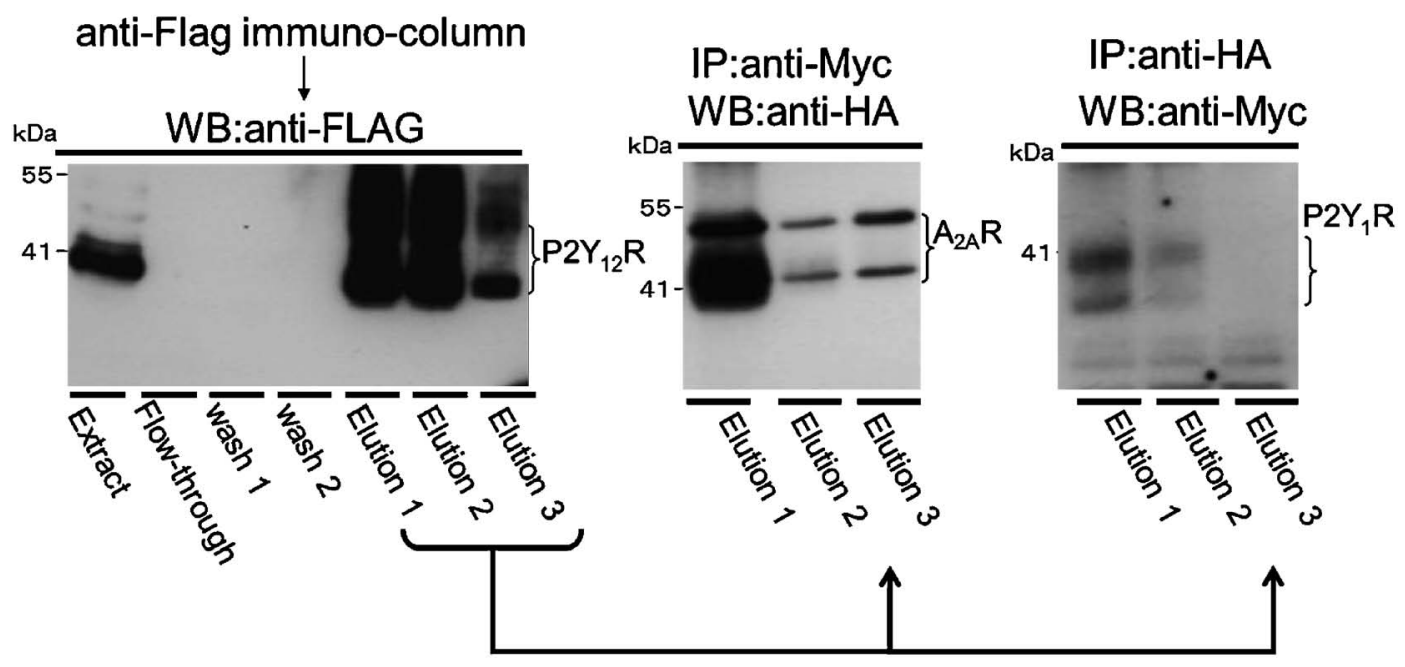

Fig. 2. Heterooligomerization of $\mathrm{A}_{2 \mathrm{~A}} \mathrm{R}, \mathrm{P} 2 \mathrm{Y}_{1} \mathrm{R}$ and $\mathrm{P} 2 \mathrm{Y}_{12} \mathrm{R}$ Examined Using Immuno-column and Co-immunoprecipitation Methods in Transfected HEK293T Cells

HEK293T cell lysates co-transfected with $3 \mathrm{HA}-\mathrm{A}_{2 \mathrm{~A}} \mathrm{R}$, Myc-P2 $\mathrm{Y}_{1} \mathrm{R}$ and FLAG-P2 $\mathrm{Y}_{12} \mathrm{R}$ were applied to anti-FLAG immuno-column (left panel) . Eluate including FLAG-P2 $\mathrm{Y}_{12} \mathrm{R}$ were immunoprecipitated with anti-Myc (middle panel) or anti-HA (right panel), and precipitates were analyzed by Western blotting with anti$\mathrm{HA}$ (middle panel) and anti-Myc (right panel) antibodies. Anti-Myc antibody precipitated $3 \mathrm{HA}-\mathrm{A}_{2 \mathrm{~A}} \mathrm{R}$ coimmunoprecipitated with Myc-P2 $\mathrm{Y}_{1} \mathrm{R}$ (middle panel) . Anti-HA antibody precipitated Myc-P2 $\mathrm{Y}_{1} \mathrm{R}$ coimmunoprecipitated with $3 \mathrm{HA}-\mathrm{A}_{2 \mathrm{~A}} \mathrm{R}$ (right panel). This figure is kindly provided from Dr. K Oyanagi (Aoyama Gakuin University). Extract, solubilized membrane extract; IP, immunoprecipitate; WB, immunoblotting with each antibody indicated. Approximate molecular masses are shown in $\mathrm{kDa}$.

これらの受容体間にもへテロ多量体形成や機能にお けるクロストークがあるのではないかと考え，検討 を始めた．まず HEK293T 細胞に 3 種類の夕グを付 加した受容体 (3HA-A ${ }_{2 \mathrm{~A}} \mathrm{R}, \mathrm{Myc}-\mathrm{P} 2 \mathrm{Y}_{1} \mathrm{R}$, Flag-P2 $\mathrm{Y}_{12}$ R）をすべて同時に共発現させ，細胞膜を可溶化し たのち，抗 Flag イムノカラムに結合させた（Fig. 2). 結合した成分が Flag-P $2 \mathrm{Y}_{12} \mathrm{R}$ を含んでいること を観察した（Fig. 2, Left）上で，抗 HA 抗体ある いは抗 Myc 抗体で免疫沈降を行い, 各々抗 Myc 抗 体あるいは抗 HA 抗体でイムノブロットを行うこ とで, $\mathrm{A}_{2 \mathrm{~A}} \mathrm{R} / \mathrm{P} 2 \mathrm{Y}_{1} \mathrm{R} / \mathrm{P} 2 \mathrm{Y}_{12} \mathrm{R}$ の三成分からなるへテ 口多量体を検出することができた（Fig. 2).17) ま た，健常ヒトボランティアから採血した血液から調 製した血小板においては，免疫沈降によって少なく とも $\mathrm{A}_{2 \mathrm{~A}} \mathrm{R} / \mathrm{P} 2 \mathrm{Y}_{1} \mathrm{R}, \mathrm{A}_{2 \mathrm{~A}} \mathrm{R} / \mathrm{P} 2 \mathrm{Y}_{12} \mathrm{R}$ の間の共沈降が みられ, 強制発現系のみならず血小板での内在発現 受容体においてもへテロ多量体が形成されているこ とが示唆された. ${ }^{17)}$

次にシグナル伝達に関してクロストークがみられ るかどうかを解析するため, Gq に共役している $\mathrm{P}_{2} \mathrm{Y}_{1} \mathrm{R}$ のシグナル伝達を, 細胞内 $\mathrm{Ca}^{2+}$ アッセイに よって評価した. HEK293T 細胞に 3 種類の受容体 を共発現させ， $\mathrm{P} 2 \mathrm{Y}_{1} \mathrm{R}, \mathrm{P} 2 \mathrm{Y}_{12} \mathrm{R}$ アゴニストである 2-methylthio-ADP (2MeSADP) を作用させたとこ
ろ明確な細胞内 $\mathrm{Ca}^{2+}$ 上昇がみられ， $\mathrm{P} 2 \mathrm{Y}_{1} \mathrm{R}$ 選択的 アンタゴニスト N6-methyl-2'-deoxyadenosine-3', 5'-bisphosphate（MRS2179）によって完全に遮断 されたため, $\mathrm{P} 2 \mathrm{Y}_{1} \mathrm{R}$ 経由のシグナル伝達が正常に 起こつていることを同定した. ${ }^{18)}$ 興味深いことにこ の反応は $\mathrm{A}_{2 \mathrm{~A}} \mathrm{R}$ 選択的アンタゴニスト 4- (2- [7-amino-2-(2-furyl) $[1,2,4]$-triazolo $[2,3-\alpha][1,3,5]$ triazin5-yl amino] ethyl) phenol（ZM241385) 及び $\mathrm{P} 2 \mathrm{Y}_{12} \mathrm{R}$ 選択的アンタゴニスト N6- (2-methyl-thioethyl) -2( 3,3,3-trifluoropropylthio ) $-\beta, \gamma$-dichloromethyleneATP (ARC69931MX) によって有意に抑制され, $\mathrm{A}_{2 \mathrm{~A}} \mathrm{R} / \mathrm{P} 2 \mathrm{Y}_{1} \mathrm{R}, \mathrm{P} 2 \mathrm{Y}_{12} \mathrm{R} / \mathrm{P} 2 \mathrm{Y}_{1} \mathrm{R}$ 間でのシグナルのク ロストークが示唆された. 本反応の生理的役割につ いて考察するため, より生体内に近い環境でアッセ イを行うことを考え，HEK293T 細胞に内在的に発 現しているこれらの受容体に対しても同様の実験を 行った。するとZM241385 による抑制は同様に観 察されたが，ARC69931MXについては抑制傾向が みられるものの有意な差は観察できなかった。強制 発現系と内在発現系における各々の受容体の発現量 の差や，受容体の発現，多量体形成や細胞内での機 能を助ける他の因子の発現量によるものと考えるこ とができる.

続いてこの反応が血小板内在性のプリン受容体に 

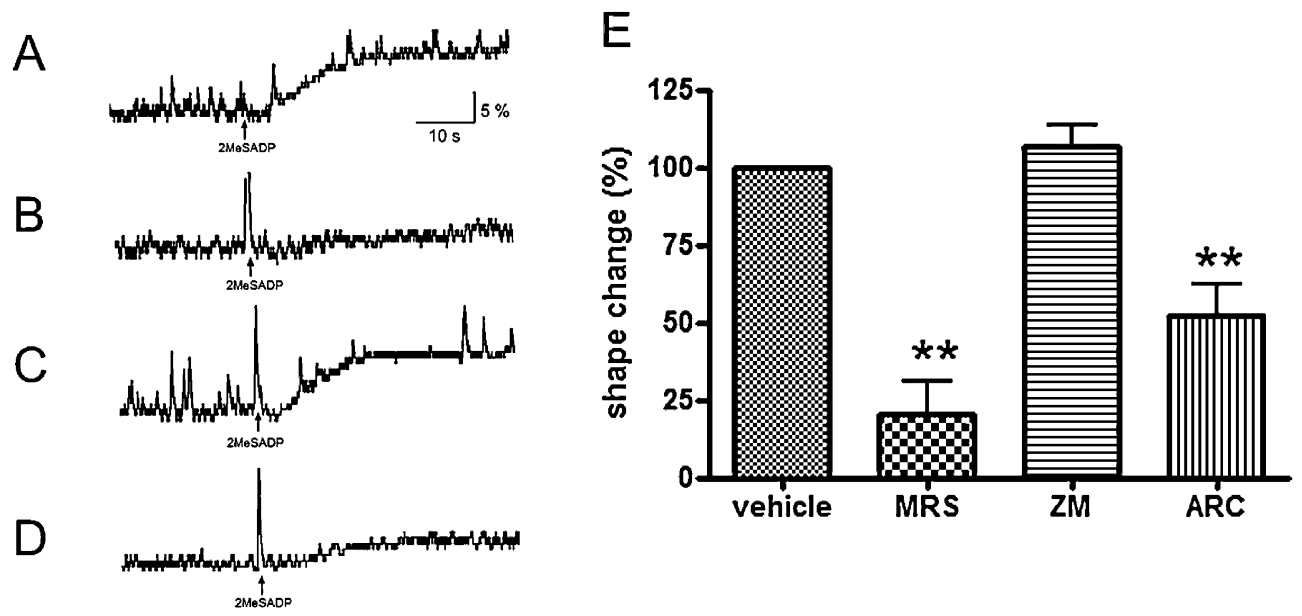

Fig. 3. Effect of Antagonists on $0.1 \mu \mathrm{M}$ 2MeSADP-induced Platelet Shape Change Using Human Platelet-rich Plasma

Representative traces of platelet shape change in the presence of $10 \mathrm{~mm}$ EGTA induced by $0.1 \mu \mathrm{M} 2 \mathrm{MeSADP}$ and the effect of vehicle (A), $10 \mu \mathrm{M}$ MRS2179 (B), $10 \mu \mathrm{M}$ ZM241385 (C) or $10 \mu \mathrm{M}$ ARC69931MX (D) are shown. (E) Differences between platelet shape change before stimulation and 1 min after stimulation. Results show the mean of four independent experiments. ${ }^{* *} p<0.05 v s$. vehicle by Dunnett's test.

おいても観察されるかどうかを検討するため，健常 ヒト血液から単離した洗浄血小板を用いて同様の アッセイを行った。 その結果, 2MeSADPによって 明確な $\mathrm{Ca}^{2+}$ 上昇がみられ，MRS2179によって完 全にブロックされたので, 血小板での $\mathrm{P} 2 \mathrm{Y}_{1} \mathrm{R}$ の正 常なシグナル伝達を観察できた。加えて,

ZM241385 による 2MeSADP 誘発性細胞内 $\mathrm{Ca}^{2+}$ 濃 度上昇の減弱作用とがあり，ARC69931MXによっ て有意な作用がみられなかつたので，HEK293T の 内在発現受容体刺激時と同等の結果を得ることがで きた.

血小板における $\mathrm{P} 2 \mathrm{Y}_{1} \mathrm{R}-\mathrm{Gq}$ シグナルは形態変化 に大きく関与している. ${ }^{14)}$ そこで次に ZM241385 に よる 2MeSADP 誘発性細胞内 $\mathrm{Ca}^{2+}$ 濃度上昇の減弱 作用が血小板機能に与える影響を検討するため， ヒ 卜多血小板血漿を用いて形態変化を解析することに した，方法としては，形態変化による体積の増大に 伴う光透過率をアグリゴメーターによって測定する 比濁法を用いた。その結果興味深いことに， 2MeSADP 刺激によってみられる形態変化は ZM241385によっては有意な影響を受けず， ARC69931MX によって有意な抑制がみられるとい う, $\mathrm{Ca}^{2+}$ 濃度変化とは異なる結果が得られた (Fig. 3). 血小板における ADP 誘発性形態変化に は， Gq を介する経路と並んで $\mathrm{G} 12 / 13$ を介する経 路の存在が報告されている. ${ }^{19)}$ 今回の結果から, 血 小板における $\mathrm{A}_{2 \mathrm{~A}} \mathrm{R}$ は $\mathrm{P} 2 \mathrm{Y}_{1} \mathrm{R}$ の $\mathrm{Gq}$ 経路に変化を
与えるものの，形態変化に影響を及ぼすほどではな く, 対して $\mathrm{P} 2 \mathrm{Y}_{12} \mathrm{R}$ は $\mathrm{P} 2 \mathrm{Y}_{1} \mathrm{R}$ の $\mathrm{G} 12 / 13$ 経路に作用 を及ぼすことで形態変化の制御に係わっているので はないかと考えることができる．詳細なメカニズム については更なる研究を必要とするが，いずれにし ても血小板において高発現しているプリン受容体が クロストークによって ATP とその代謝産物の微妙 な濃度変化に対応して血小板機能を制御している可 能性が示唆される。

謝辞本総説に関する研究は東京都神経科学総 合研究所（現 東京都医学総合研究所）中田裕康副 参事研究員及び東北大学大学院薬学研究科 故 -中 畑則道教授の指導の下によって実施されたものであ り，この場を借りて心から感謝申し上げます。

利益相反＼cjkstart開示すべき利益相反はない.

\section{REFERENCES}

1) Birdsall N. J., Trends Pharmacol. Sci., 31, 499-508 (2010).

2) Lee L. T., Ng S. Y., Chu. J. Y., Sekar R., Harikumar K. G., Miller. L. J., Chow B. K., FASEB J., 28, 2632-2644 (2014).

3) Daniels D. J., Lenard N. R., Etienne C. L., Law P. Y., Roerig S. C., Portoghese P. S., Proc. Natl. Acad. Sci. USA, 102, 19208-19213 (2005). 
4) Akgün E., Javed M., Lunzer M. M., Smeester B. A., Beitz A. J., Portoghese P. S., Proc. Natl. Acad. Sci. USA, 110, 11595-11599 (2013).

5) Yegutkin G. G., Biochim. Biophys. Acta, 1783, 673-694 (2008).

6) Abbracchio M. P., Burnstock G., Boeynaems J. M., Barnard E. A., Boyer J. L., Kennedy C., Knight G. E., Fumagalli M., Gachet C., Jacobson K. A., Weisman G. A., Pharmacol. Rev., 58, 281-341 (2006).

7) Fredholm B. B., IJzerman A. P., Jacobson K. A., Linden J., Müller C. E., Pharmacol. Rev., 63, 1-34 (2011).

8) Yoshioka K., Saitoh O., Nakata H., Proc. Natl. Acad. Sci. USA, 98, 7617-7622 (2001).

9) Suzuki T., Namba K., Tsuga H., Nakata H., Biochem. Biophys. Res. Commun., 351, 559565 (2006).

10) Yoshioka K., Saitoh O., Nakata H., FEBS. Lett., 523, 147-151 (2002).

11) Suzuki T., Namba K., Mizuno N., Nakata H.,
Methods Enzymol., 521, 239-257 (2013).

12) Namba K., Suzuki T., Nakata H., BMC Res. Notes, 3, 323 (2010).

13) Yoshioka K., Hosoda R., Kuroda Y., Nakata H., FEBS Lett., 531, 299-303 (2002).

14) Goggs R., Williams C. M., Mellor H., Poole A. W., Biochem. J., 466, 431-442 (2015).

15) Cattaneo M., Gachet C., Haematologica, 86, 346-348 (2001).

16) Ledent C., Vaugeois J. M., Schiffmann S. N., Pedrazzini T., El Yacoubi M., Vanderhaeghen J. J., Costentin J., Heath J. K., Vassart G., Parmentier M., Nature, 388, 674-678 (1997).

17) Nakata H., Suzuki T., Namba K., Oyanagi K., J. Recept. Signal Transduct. Res., 30, 337346 (2010).

18) Suzuki T., Obara Y., Moriya T., Nakata H., Nakahata N., FEBS Lett., 585, 3978-3984 (2011).

19) Paul B. Z., Daniel J. L., Kunapuli S. P., J. Biol. Chem., 274, 28293-28300 (1999). 